\title{
ENTREPRENEURIAL ORIENTATION, ROLE OF THE GOVERNMENT, AND PARTNERSHIP ON MARKETING PERFORMANCE OF FURNITURE EXPORT SMES: A STUDY ON FURNITURE EXPORT COMPANIES IN JEPARA
}

\author{
Samsul Arifin', Nurul Komaryatin ${ }^{2}$ \\ ${ }^{1,2}$ Faculty of Economics and Business, Universitas Islam Nahdlatul Ulama, Jepara, Indonesia \\ e-mails: ${ }^{1}$ samsul@unisnu.ac.id; ${ }^{2}$ nurul@unisnu.ac.id
}

Received May 28, 2020; accepted June 30, 2020; published July 1, 2020.

\begin{abstract}
Objective: The study is to analyze the role of the government, entrepreneurial orientation and partnership on marketing performance in the Jepara furniture industry. The objects of the research are furniture export companies in Jepara. Research Design \& Methods: The sample was 100 respondents and the sampling technique was the simple random sampling technique. The data analysis uses the PLS technique. Findings: The testing results using PLS illustrates that partnership on marketing performance shows the t value of 0.045974; entrepreneurial orientation on marketing performance shows the $\mathrm{t}$ value of 1.747034; while the role of the government on marketing performance shows the $t$ value of 2.985408. The test results were compared using $t$ tables of 1.66023 . The results showed that the role of the government had a positive and significant effect on marketing performance seen from $t$ value $>t$ table. Entrepreneurial orientation also had a positive and significant effect on marketing performance obtained from $t$ value $>t$ table. However, the partnership had no significant effect on marketing performance since $\mathrm{t}$ value $<\mathrm{t}$ table. Implications $\boldsymbol{\&}$ Recommendations: This study recommends that companies need to pay attention to entrepreneurial orientation and government policies because these two factors are significant determinants of company marketing performance. Increasing partnerships is also important to develop company progress. Contribution \& Value Added: This research adds the theoretical contributions to marketing management. Practically, the results of this research can be utilized by furniture export companies to increase overseas sales.
\end{abstract}

Keywords: entrepreneurial orientation; role of the government; partnership; export marketing performance.

JEL codes: L14, L26, M31, M38

Article type: research paper

\section{INTRODUCTION}

Small and Medium Enterprises (SMEs) in the export-oriented furniture sector have an economic role in contributing to a country's national products by providing goods or services and contributing to export performance. SMEs have the potential to create jobs, improve the quality of human resources, increase purchasing power, and stimulate productive activities. This potential of SMEs must be maintained for business continuity and economic improvement in the regions. Economic improvement in the regions has a very big role in the welfare of society. Therefore, increasing the export performance of SMEs needs to do to create more market and employment opportunities and welfare distribution.

Furniture exports from Jepara have penetrated 114 countries from 5 continents with an export value of Rp. 2.3 trillion in 2016, Data from the Industry and Trade Office (2017). In terms of turnover and the number of workers, Jepara is the largest furniture industry cluster in Indonesia. Jepara is able to 
produce an average of 400 shipping containers for the export market each month. This export capacity usually increases around September to March reaching 600 to 700 containers per month, data from the Industry and Trade Office (2017). Therefore, the increase in demand must be followed by the internal capabilities of export companies in producing furniture in large scale to make the company trusted by many international buyers.

Table 1. Export Value of Furniture SMEs in Jepara in 2013-2017

\begin{tabular}{cccr}
\hline Year & Exporter & Country & \multicolumn{1}{c}{ Value (USD) } \\
\hline 2013 & 219 & 110 & $98,877,259.57$ \\
2014 & 223 & 106 & $114,781,164.54$ \\
2015 & 296 & 113 & $150,320,779.41$ \\
2016 & 307 & 114 & $174,042,524.73$ \\
2017 & 398 & 111 & $166,862,444.20$ \\
\hline
\end{tabular}

Source: Disperindag (2017), (processed)

In Table 1, it can be seen that the export value of Jepara Furniture SMEs experienced a significant decline from 2016 to 2017. The decline was caused by not achieving the company's target, due to suboptimal export marketing performance. Therefore, the role of furniture exporters is needed to boost the marketing performance of export furniture. Furniture exporters are always required not to give up easily to convince customers and to carry out the right sales strategy. To improve export marketing performance, the role of exporters must receive attention. The most likely anticipation for furniture exporters in Jepara Regency is to improve management capabilities to increase marketing.

Some previous research results state that entrepreneurial orientation has a positive influence on performance (Jogaratnam and Tse, 2006; Van Zyl and Mathur-Helm, 2007; Li, Zhao, Tan, and Liu, 2008) and some explain that entrepreneurial orientation has negative influence on performance (Naldi, et al., 2007; Frishammar and Hörte, 2007; Baker and Sinkula, 2009). The aspects of government policy, socio-cultural and economic aspects, and the role of related institutions have a positive and significant influence on the performance of micro and small businesses. Similar research was also carried out by Lee \& Tsang (2001) who stated that government policy has a strategic influence on business performance.

There are controversial research results in the relationship among variables of entrepreneurial orientation, market orientation, marketing environment and marketing performance. The dimensions used to measure entrepreneurial orientation in this study are based on Covin \& Slevin (1989), which are innovative, proactive and courage to take risks, while the dimensions used to measure market orientation are based on Narver \& Slater (1990) consisting of customer orientation, orientation on competitors, coordination between functions, long-term focus and profitability.

This research is conducted to analyze entrepreneurial orientation, role of the government, and partnerships on export marketing performance. This research is expected to give theorethical contribution in the field of marketing management, especially marketing performance. Practically, the results of this research can be utilized by furniture export companies to increase overseas sales.

\section{LITERATURE REVIEW}

\section{Marketing Performance}

Ferdinand (2014) explains that marketing performance is a measure of achievement obtained from the overall marketing process activities of a company or organization. It is also seen as a concept that is used as a measure of the extent to which market performance has been achieved by a company's products. Meanwhile, according to Hatta (2015) marketing performance is the output of all businesses and marketing strategies that have been run by entrepreneurs.

Frösén, Tikkanen, Jaakkola, \& Vassinen (2013) and Homburg, Artz, \& Wieseke (2012) suggest that the successful implementation of a proactive marketing strategy requires the adoption of a comprehensive marketing performance appraisal system (MPAS), which consists of a set of formal routines and procedures which uses information gathered through a series of marketing metrics to 
improve the effectiveness and efficiency of marketing investments, with the final goal of improving company performance. Barczak, Hultink, \& Sultan (2008) explain that marketing performance is the level of new products that meet customer expectations regarding sales, greater market share than its competitors, profitability, and the company's ability to respond to markets and create customer satisfaction. In addition, it is reflected in profitability, sales growth, and market share. Marketing performance measures must capture company performance at current and future levels. More explicitly, the broad and balanced conceptualization of performance, including financial and nonfinancial measures, will help marketers to fully understand the performance consequences of their strategies (Varadarajan \& Jayachandran, 1999).

\section{Entrepreneurial Orientation}

Entrepreneurial orientation plays an important role in improving business performance. Miller \& Friesen (1982) revealed that entrepreneurial orientation became an accepted meaning to explain business performance. According to Morris, Schindehutte, \& LaForge (2002), marketing entrepreneurship is an integrative construct that represents a different approach to imagining business relationships with markets and the role of marketing in companies. Entrepreneurial marketing is fundamentally driven by opportunities and ways of thinking and acting to look for them. Whereas Gosselin (2005) explains that there is a significant relationship between established entrepreneurial orientation and company performance. Entrepreneurial oriented companies are constantly looking for ways to improve their competitive position with new products and innovations. A company's entrepreneurial orientation is an indication of its company's internal environment that encourages creativity and allows decisively introducing and reaping the results of innovation success (Zahra, 2018).

In developing an entrepreneurial orientation, it is defined as a strategic process carried out by the company; entrepreneurial orientation reflects the policies and practices that form the basis for entrepreneurial decision making and actions (Rauch, Wiklund, Lumpkin, \& Frese, 2009). Webb, Ireland, Hitt, Kistruck, \& Tihanyi (2011) explain that marketing activities, the entrepreneurial process of how the institutional environment, including market conditions, influences marketing practices in entrepreneurial ventures. Entrepreneurial orientation that has been owned by the company has a positive effect in creating corporate value, where the influence of direct decisions on entrepreneurial behavior and overflowing authority are characteristics of entrepreneurship in organizations, thus encouraging entrepreneurial behavior (Keil, Maula, \& Syrigos, 2017).

\section{Role of the Government}

Cohen (2009) defines a role as behavior expected by someone else from someone who occupies a certain status. The Indonesian government plays an important role in empowering SMEs as mandated in Law No. 20 of 2008 concerning Micro, Small and Medium Enterprises. The objectives of empowering Micro, Small and Medium Enterprises are (1) to create a balanced structure, development and national economic justice; (2) to process and develop the ability of small and medium businesses to become strong and independent businesses; and (3) to increase the role of small and medium-sized companies in regional development, job creation, fair distribution of income, economic growth, and reducing people's poverty. The role of government also influences entrepreneurship.

\section{Partnership}

Hafsah (2000) argues that partnership is a business strategy carried out by two or more parties in a certain period of time to achieve mutual benefits with the principle of mutual need and encouragement. Meanwhile, according to Suryana (2013), a partnership is collaboration between two or more people carried out together in running a company. In addition, Zimmerer \& Scarborough (2005) mentions that a partnership is collaboration accomplished by two or more people who have a company with the aim of making a profit.

Partnership according to Mohr \& SpePNan (1994) is a strategic relationship that is deliberately designed or built between companies to achieve the goals set, mutual benefits and high 
interdependence. Through this partnership, the two companies are able to access new technology or markets, have the ability to offer broader products or services, have economies of scale in joint research or production, and have access to knowledge, and share risks and access complementary skills.

\section{Export Performance}

Dhanaraj \& Beamish (2003) explain that export performance is the intensity of exports, as a result of the company's export strategy. The company's export performance is one of the indicators used in measuring the value or success of a company that shows the ability to conduct export sales directly or indirectly. It is an export channel structure, strategic orientation and external environment (EOpara \& Kabongo, 2009).

Export performance is the result of a company achieved in international sales (Shoham, 1998). Various literatures show that there is no well-established definition of export performance or an agreement specifying an acceptable level of performance, which leads to the use of various measurement dimensions (Lages \& Sousa, 2010). Measurement of export performance might be a problem driven rather than theory driven, as studies of export performance differ in definition and overcome different problems. Export performance can be measured at different levels: product, business export, or company level (Leonidou, Katsikeas, \& Samiee, 2002).

\section{METHODS}

This research employed the Partial Least Square (PLS) method using the SmartPLS Version 2 program. The object of this research was furniture export companies in Jepara, Central Java, Indonesia consisting of 398 companies. Jepara is one of the biggest furniture exporting cities at present. Thus, this research examined the factors that determine the marketing performance of furniture export companies in Jepara. The independent variables of this study were entrepreneurial orientation (EO), the role of government (RG), and partnership (PN), while the dependent variable was marketing performance (MP). To test the relationship between the independent and dependent variable, respondents were sampled and 100 samples of furniture export companies were obtained. The sampling technique refers to Arikunto (2013), which takes a sample size of $25 \%$ of the population by using simple random sampling technique.

This research used two types of data including primary and secondary data. Secondary data was used to support primary data consisting of literature studies, journals and other information. This study also used data on the export value of Jepara Furniture SMEs in 2013-2017 obtained from the Department of Industry and Trade of Jepara Regency in 2018. Meanwhile, primary data were obtained from the results of questionnaires by respondents. The research variables were measured using 20 indicators consisting of instruments of each variable. The EO variable referred to the indicators used by Naldi et al. (2007), while the RG variable was measured by the indicators of Gede (2009). Then the PN variable was measured by indicators from Mohr \& SpePNan (1994) and the MP variable referred to the instrument of Leonidou et al. (2002).

\section{FINDING}

The hypothesis testing in this study used the Partial Least Square (PLS) method using the SmartPLS Version 2 program. The structural model is shown in Figure 1 below. 


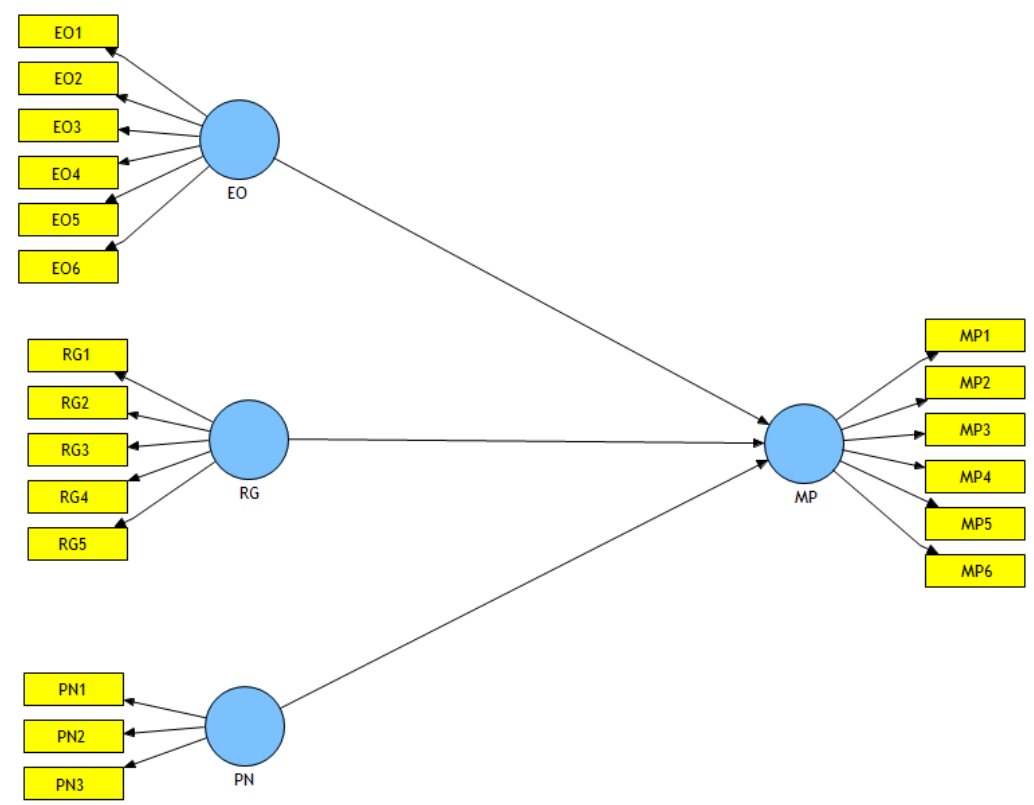

Figure 1. Structural Model

Measurement Evaluation of (Outer) Model

\section{Validity Testing}

An indicator is declared valid if it has a loading factor above 0.5 for the intended construct. The SmartPLS output for loading factor calculated through PLS Algorithm presents the results as shown in Table 2.

Table 2. Result for Outer Loadings

\begin{tabular}{lcccc}
\hline & PN & MP & EO & RG \\
\hline PN1 & 0.936626 & & & \\
PN2 & 0.893094 & & & \\
PN3 & 0.960628 & & & \\
MP1 & & 0.710002 & & \\
MP2 & & 0.723449 & & \\
MP3 & & 0.917225 & & \\
MP4 & & 0.866190 & & \\
MP5 & & 0.799580 & & \\
MP6 & & 0.807209 & & \\
EO1 & & & 0.689322 & \\
EO2 & & & 0.747276 & \\
EO3 & & & 0.807724 & \\
EO4 & & & 0.746032 & \\
EO5 & & & 0.776044 & \\
EO6 & & & 0.628597 & \\
RG1 & & & & 0.760871 \\
RG2 & & & & 0.832309 \\
RG3 & & & & 0.846710044 \\
RG4 & & & & \\
RG5 & & & & \\
\hline Source: primary data processed & & & \\
\end{tabular}

Source: primary data, processed 
The loading factor value is said to be valid or meets convergent validity when it exceeds 0.5 . Table 2 shows that the lowest loading factor is 0.610044 . It means that the indicators used in this study were valid or had fulfilled convergent validity. Figure 2 is a loading factor diagram of each indicator in the research model.

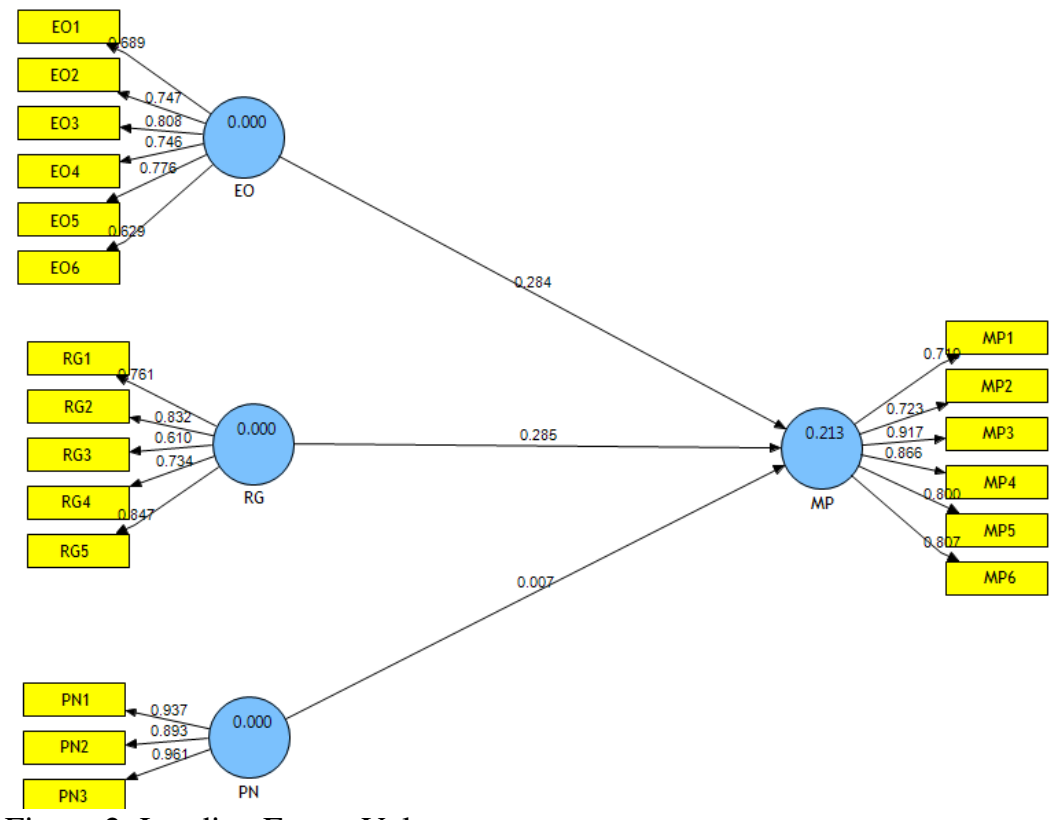

Figure 2. Loading Factor Value

Furthermore, in SmartPLS, research indicators also need to be tested for discriminant validity by cross loading as in Table 3.

Table 3. Result for Cross Loadings

\begin{tabular}{ccccc}
\hline & PN & MP & EO & RG \\
\hline PN1 & $\mathbf{0 . 9 3 6 6 2 6}$ & 0.238068 & 0.543111 & 0.259214 \\
PN2 & $\mathbf{0 . 8 9 3 0 9 4}$ & 0.142102 & 0.502593 & 0.325528 \\
PN3 & $\mathbf{0 . 9 6 0 6 2 8}$ & 0.335876 & 0.621514 & 0.394711 \\
MP1 & 0.330153 & $\mathbf{0 . 7 1 0 0 0 2}$ & 0.114760 & 0.187038 \\
MP2 & 0.107158 & $\mathbf{0 . 7 2 3 4 4 9}$ & 0.070755 & 0.295495 \\
MP3 & 0.273602 & $\mathbf{0 . 9 1 7 2 2 5}$ & 0.371360 & 0.352068 \\
MP4 & 0.364957 & $\mathbf{0 . 8 6 6 1 9 0}$ & 0.451688 & 0.367412 \\
MP5 & 0.070665 & $\mathbf{0 . 7 9 9 5 8 0}$ & 0.236377 & 0.263264 \\
MP6 & 0.165867 & $\mathbf{0 . 8 0 7 2 0 9}$ & 0.333521 & 0.271018 \\
EO1 & 0.458398 & 0.296017 & $\mathbf{0 . 6 8 9 3 2 2}$ & 0.298969 \\
EO2 & 0.585118 & 0.251845 & $\mathbf{0 . 7 4 7 2 7 6}$ & 0.174779 \\
EO3 & 0.512697 & 0.290877 & $\mathbf{0 . 8 0 7 7 2 4}$ & 0.098325 \\
EO4 & 0.422064 & 0.206662 & $\mathbf{0 . 7 4 6 0 3 2}$ & 0.245002 \\
EO5 & 0.484644 & 0.332453 & $\mathbf{0 . 7 7 6 0 4 4}$ & 0.232528 \\
EO6 & 0.168047 & 0.222327 & $\mathbf{0 . 6 2 8 5 9 7}$ & 0.244747 \\
RG1 & 0.381461 & 0.278519 & 0.317112 & $\mathbf{0 . 7 6 0 8 7 1}$ \\
RG2 & 0.325667 & 0.369430 & 0.173373 & $\mathbf{0 . 8 3 2 3 0 9}$ \\
RG3 & 0.452175 & 0.142162 & 0.346588 & $\mathbf{0 . 6 1 0 0 4 4}$ \\
RG4 & 0.067757 & 0.310532 & 0.113289 & $\mathbf{0 . 7 3 4 1 5 2}$ \\
RG5 & 0.239064 & 0.212476 & 0.275568 & $\mathbf{0 . 8 4 6 7 7 1}$ \\
\hline Source: primary data, processed & & &
\end{tabular}

An indicator is declared valid if it has the highest loading factor to the intended construct compared to loading factor to other constructs. Table 3 shows that the loading factor for PN indicators (PN1 to PN3) has a higher loading factor for the PN construct than the other constructs. As an illustration, PN1 loading factor for MP is 0.936626 which was higher than loading factor for MP (0.238068), EO 
(0.543111) and RG (0.259214). So by looking at the cross loadings above there are similar things that appear in the MP, EO, and RG indicators. Thus, latent contracts predict indicators in their block better than indicators in other block.

Another method for finding out discriminant validity is to look at the square root of average variance extracted (AVE) values. The recommended value is above 0.5. The following is the AVE value in this study. Table 4 shows that the AVE value is above 0.5 for all constructs contained in the research model. The lowest value of AVE is 0.539991 in the EO construct (Entrepreneurial Orientation).

Table 4. Average Variance Extracted (AVE)

\begin{tabular}{lc}
\hline & AVE \\
\hline PN & 0.865897 \\
MP & 0.651664 \\
EO & 0.539991 \\
RG & 0.579963 \\
PN & 0.865897 \\
\hline \multicolumn{2}{l}{ Source: primary data, processed }
\end{tabular}

\section{Reliability Testing}

Reliability test is done by looking at the composite reliability value of the blEO indicator that measures the construct. The results of composite reliability will show a satisfactory value if it is above 0.7 .

Table 5. Composite Reliability

\begin{tabular}{cc}
\hline & Composite Reliability \\
\hline PN & 0.950868 \\
MP & 0.917578 \\
EO & 0.874975 \\
RG & 0.872096 \\
\hline \multicolumn{2}{l}{ Source: primary data, processed }
\end{tabular}

Table 5 shows that the composite reliability value for all constructs is above 0.7 which indicates that all constructs in the estimated model meet the discriminant validity criteria. The lowest composite reliability value is 0.872096 in the RG construct (Role of the Government). The reliability test can also be strengthened with Cronbach's alpha where SmartPLS Version 2 output shows the following results.

Table 6. Cronbach's Alpha

\begin{tabular}{lc}
\hline & Cronbach's Alpha \\
\hline EO & 0.874856 \\
MP & 0.821544 \\
RG & 0.896377 \\
PN & 0.882109 \\
\hline
\end{tabular}

Source: primary data, processed

The recommended value is above 0.6 and in Table 6 shows that the Cronbach's alpha value for all constructs is above 0.6. The lowest value is 0,821544 in the MP construct (Marketing Performance). Communality and redundancy measurements with the SmartPLS Version 2 program show the following results.

Table 7. Communality and Redundancy

\begin{tabular}{lcc}
\hline & Communality & Redundancy \\
\hline PN & 0.865897 & \\
MP & 0.651663 & 0.002381 \\
EO & 0.539991 & \\
RG & 0.579964 & \\
\multicolumn{2}{l}{ Source: primary data, processed }
\end{tabular}


Table 7 indicates that the value of communality at all constructs is above 0.5 , which reinforces the test results with composite reliability and Cronbach's alpha. Furthermore, the MP Redundancy value is 0.002381 which is included in the high category.

\section{Structural Model Testing (Inner Model)}

After the estimated model meets the outer model criteria, the structural model (inner model) is then tested. Following is the R-Square value in the construct.

Table 8. R Square

\begin{tabular}{lc} 
& \multicolumn{1}{c}{ R Square } \\
\hline EO & \\
MP & 0.213430 \\
RG & \\
PN & \\
\hline \multicolumn{2}{l}{ Source: primary data, processed }
\end{tabular}

Table 8 the construct of marketing performance (MP) which means that entrepreneurial orientation (EO), the role of government (RG), and partnership (PN) are able to explain the variance in marketing performance

Hypothesis testing in SmartPLS is seen in the total effects (mean, stdev, t-values) calculated through bootstrapping shown in the following table.

Table 9. Hypothesis Testing

\begin{tabular}{cccccc}
\hline & $\begin{array}{c}\text { Original } \\
\text { Sample }(\mathrm{O})\end{array}$ & $\begin{array}{c}\text { Sample Mean } \\
(\mathrm{M})\end{array}$ & $\begin{array}{c}\text { Standard } \\
\text { Deviation } \\
(\mathrm{STDEV})\end{array}$ & $\begin{array}{c}\text { Standard Error } \\
(\text { STERR })\end{array}$ & $\begin{array}{c}\text { T Statistics } \\
(|\mathrm{O} / \mathrm{STERR}|)\end{array}$ \\
\hline PN $->$ MP & 0.006763 & 0.011795 & 0.147113 & 0.147113 & 0.045974 \\
EO -> MP & 0.284499 & 0.279097 & 0.162847 & 0.162847 & 1.747034 \\
RG -> MP & 0.285351 & 0.314584 & 0.095582 & 0.095582 & 2.985408 \\
\hline
\end{tabular}

Source: primary data, processed

Table 9 shows that the relationship between EO and MP is the T-statistic of 1.75>t table (1.66). The original sample estimate value is positive, that is 0.284499 , which shows that the direction of the relationship between EO and MP is positive. Thus the $\mathrm{H} 1$ hypothesis in this study which states that 'entrepreneurial orientation has a positive effect on marketing performance' is accepted.

Table 9 shows that the relationship between GM and MP is significant with a T-statistic of 2.985408> $\mathrm{t}$ table (1.66023). The original sample estimate value is positive that is equal to 0.285351 which indicates that the direction of the relationship between GM and MP is positive. Thus the H2 hypothesis in this study which states that 'the role of government has a positive effect on marketing performance' is accepted.

Table 9 shows that the relationship between PN and MP is not significant with a T-statistic of $0.045974<t$ table (1.66023). The original sample estimate value is positive that is equal to 0.006763 which shows that the direction of the relationship between PN and MP is positive. Thus the H3 hypothesis in this study which states that 'partnership has a positive effect on marketing performance' is rejected.

\section{DISCUSSION}

\section{Entrepreneurial Orientation Has a Positive Effect on Marketing Performance}

The test results show that the relationship between entrepreneurial orientation and marketing performance is t-statistic of 1.747034> t table (1.66023). The original sample estimate value is positive, that is 0.284499 , which shows that the direction of the relationship between them is positive. Thus, the $\mathrm{H} 1$ hypothesis in this study which states that 'entrepreneurial orientation has a positive effect on marketing performance' is accepted. The results of this study are supported by some researches of 
Jogaratnam \& Tse (2006); Van Zyl \& Mathur-Helm (2007) and Li et al. (2008), who mentions that entrepreneurial orientation has a positive and significant effect on marketing performance.

Based on these empirical findings, exporters of furniture companies in Jepara say they agree to develop a business integration process with various stakeholders. This is to get support from strong stakeholders to help win more resources and will further optimize export performance based on trust and commitment made by the company. Integration is one of the important things that can support the development of the export furniture business because with many connections, companies can more easily develop and expand business networks. The level of understanding of entrepreneurial orientation for furniture SMEs in Jepara is already good. However, their product innovation capability is still lacking, even though it is a very important indicator in entrepreneurial orientation. Entrepreneurial orientation is one of the company's strategic orientations in achieving marketing capabilities by prioritizing innovation capabilities.

\section{The Role of Government Has a Positive Effect on Marketing Performance}

The test results show that the relationship between the role of government and marketing performance is significant with a t-statistic of 2.985408>t table (1.66023). The original sample estimate value is positive that is equal to 0.285351 which shows that the direction of the relationship between them is positive. Thus the $\mathrm{H} 2$ hypothesis in this study which states that 'the role of government has a positive effect on marketing performance' is accepted. The results of this study are supported by a research of Lee \& Tsang (2001) which state that the role of government has a significant effect on marketing performance.

Based on empirical findings, the improvements in comparative advantage and Jepara furniture export performance have been carried out well so that the company's profit growth has increased. However, policies are needed to facilitate export producers to encourage trade cooperation with other countries, both bilateral and multilateral cooperation. The Jepara furniture export performance achieved by the export furniture SMEs in Jepara is in the high category. Jepara export furniture SMEs in improving export performance need to improve competitor knowledge management, where from the results of descriptive analysis it is known that the index value for competitor knowledge management is still lacking. The existence of knowledge transfer in Jepara export furniture SMEs can be tracked through appropriate technology knowledge transfer activities, which are carried out by sharing experiences and practice directly.

Many government programs are made for SMEs. It aims to encourage and grow resilient and modern small entrepreneurs as the people's economic power and small entrepreneurs who are able to strengthen the structure of a more efficient national economy. Product innovation is needed in business competition, especially in the export furniture business. Business entities need partnerships that basically combine the activities of several businesses. Therefore, it is needed an adequate organization. In the system concept approach, it is known that the organization basically consists of a number of units or sub-units that interact with each other and are interdependent.

\section{Partnership Has a Positive Effect on Marketing Performance}

The test results show that the relationship between partnerships and marketing performance is not significant with $\mathrm{t}$-statistics of $0.045974<\mathrm{t}$ table (1.66023). The original sample estimate value is positive that is equal to 0.006763 which shows that the direction of the relationship between them is positive. Thus, the H3 hypothesis in this study which states that 'partnership has a positive effect on marketing performance' is rejected. The results of this study are not in line with researches by Mohr and Spekman (1994) and Racela \& Thoumrungroje (2014) which mention that partnerships have a significant effect on export marketing performance.

Based on empirical findings, the relationship between small furniture industry entrepreneurs with showroom owners and intermediary traders generate a partnership model with a trade pattern, while the relationship with a home industry bring forth a production pattern partnership model. Enhancing partnerships in export performance is a commitment to work together in the long term. This 
collaboration is carried out to encourage quality improvement and management of SMEs to meet the needs and criteria of large scale industries. The purpose of cooperation between SMEs and large industries in the furniture sector is primarily to meet the export market.

The partnership is a joint business that is expected to provide benefits for Jepara furniture companies. However, it does not work in Jepara. Furniture companies will run more optimally if they are able to establish cooperation with companies engaged in investment in housing, apartments, hotels, or restaurants because these companies will definitely need furniture to complete their business. Therefore, it is acceptable if Jepara furniture SMEs try to establish cooperation with these companies so that their furniture businesses are smoother in achieving success. In this case, to create information disclosure to export furniture business partners, they need to update transaction information relating to business partners to create trust and peace. Furniture companies will be able to have a long-term and mutually beneficial partnership with both parties if there is openness, honesty, and togetherness to make it difficult for them to move to other business partners.

Efforts to increase partnerships in order to improve export performance can be done by involving partners in advancing business to create a democratic environment. The company continues to increase cooperation to maintain business continuity because the export furniture business in Jepara cannot be separated from other craftsmen. Furniture export companies in Jepara can be categorized into three partner groups. The first group consists of integrated companies, which produce finished products or semi-finished products from unprocessed round wood. This is a major partner in the furniture company so that the products have high quality. The second group consists of wood piling and sawmills companies which focus on the initial processing of raw materials to produce sawn timber for the needs of the third group. This second group is a partner with requirements regarding the legality of wood used for furniture products in Jepara Regency. The third group is a workshop that uses sawn wood and various components to produce finished products. This third group has the important role in modifying furniture products so that the quality of their products is unique to make furniture demand increase.

The partnership pattern is a business pattern that is difficult to move to other business partners. Business partnerships between SMEs and large companies need to be accompanied by coaching and developments with due regard to the principles of mutual need, strengthening, and benefit. Export furniture SMEs are prepared in advance to strengthen the transaction position. With this capability, their business will be more stable and cooperation will be harmonious. Efforts made with their business partners will create strong positions and transaction to establish equal, mutually needed, mutually reinforcing, and mutually beneficial partnerships to make them not easy to move to other business partners.

Partnership is a major determinant of export performance. Therefore, it is necessary to have an anticipatory policy towards the supply and demand of Indonesian exports. The information can be obtained through trade representatives such as the International Trade Promotion Center (ITPC) or Indonesian trade attaches in trading partner countries. In addition, to improve the ability to project export performance, it is important to carry out analyzes with structural modeling or general balance that can predict well the impact of changes in economic performance in partner countries on the dynamics of national exports. Furthermore, Jepara furniture exports companies are expected to not only depend on one or several export destination countries. The companies must always actively seek market opportunities through the information network and always improve export quality by increasing better quality control (QC) by exercising multiple layers of control.

\section{CONCLUSION}

The results of the export marketing performance research in Jepara district, entrepreneurship orientation, the role of the government, and partnerships show that entrepreneurial orientation and the role of government have a positive and significant impact on the marketing performance of the furniture industry in Jepara. Meanwhile, the partnership has positive and not significant effect on the marketing performance of the furniture industry in Jepara.. 
Increasing the company's export performance must foster good relations with buyers so that the cooperation or partnership relationships that are established in export destinations become more harmonious and sustainable. In addition, to improve the ability to project export performance, it is necessary to carry out analyzes with more complex modeling by doing structural modeling or general balance that can predict well the impact of changes in economic performance in partner countries on the dynamics of national exports. Besides that, Jepara furniture export companies are expected to not only depend on one or several export destination countries. The company must always actively seek market opportunities through the information network and always improve export quality by increasing better quality control (QC) by laying out control.

Although this research has advantages compared to previous studies that have been done before, this study also has limitations. One limitation of this study is that it does not pay attention to the responses of local entrepreneurs or foreign capital companies. For this reason, future research needs to be conducted that has the same scientific basis, but with research samples that are distinguished between local or Indonesian companies and foreign capital companies.

Based on the results of this study, researchers hope this research can be beneficial for furniture export companies in increasing overseas sales. The company is expected not to rule out entrepreneurship orientation factors and government policies. In conducting sales and production, furniture export companies can collaborate with outside parties, such as partners. Partnership in Jepara actually has a strong factor in improving the progress of the company because the people of Jepara have been taught to work together in building community progress. However, partnerships are underestimated by some companies. Researchers also hope that further research can be done because researchers recognize that humans are not free from mistakes.

\section{ACKNOWLEDGEMENT}

Appreciation is given to the Management Study Program, Economics and Business Faculty of Universitas Islam Nahdlatul Ulama (Unisnu) Jepara and Institute of Research and Community Service (LPPM) Unisnu Jepara Indonesia.

\section{REFERENCES}

Arikunto, S. (2013). Prosedur Penelitian: Suatu Pendekatan Praktik. Jakarta: Rineka Cipta.

Baker, W. E., \& Sinkula, J. M. (2009). The Complementary Effects of Market Orientation and Entrepreneurial Orientation on Profitability in Small Businesses. Journal of Small Business Management, 47(4), 443-464. https://doi.org/10.1111/j.1540-627X.2009.00278.x

Barczak, G., Hultink, E. J., \& Sultan, F. (2008). Antecedents and Consequences of Information Technology Usage in NPD: A Comparison of Dutch and U.S. Companies. Journal of Product Innovation Management, 25(6), 620-631. https://doi.org/10.1111/j.1540-5885.2008.00326.x

Cohen, B. J. (2009). Peranan Sosiologi, Suatu Pengantar. Jakarta: Rineka Cipta.

Covin, J. G., \& Slevin, D. P. (1989). Stategic Management of Small Firms in Hostile and Benign $\begin{array}{llll}\text { Environments. } \quad \text { Strategic } & \text { Management }\end{array}$ https://doi.org/10.1002/smj.4250100107

Dhanaraj, C., \& Beamish, P. W. (2003). A Resource-based Approach to The Study of Export Performance. Journal of Small Business Management, 41(3), 242-261.

Dinas Perindustrian dan Perdagangan (Disperindag). (2017). Data Ekspor Mebel Kabupaten Jepara.

Ferdinand, A. (2014). Metode Penelitian Manajemen (5th ed.). Semarang: Badan Penerbit Universitas Diponegoro.

Frishammar, J., \& Hörte, S. A. (2007). The Role of Market Orientation and Entrepreneurial Orientation for New Product Development Performance in Manufacturing Firms. Technology Analysis \& Strategic Management, 19(6), 765-788. https://doi.org/10.1080/09537320701711231

Frösén, J., Tikkanen, H., Jaakkola, M., \& Vassinen, A. (2013). Marketing Performance Assessment Systems and The Business Context. European Journal of Marketing, 47(5/6), 715-737. https://doi.org/10.1108/03090561311306688 
Gede, D. (2009). Mengembangkan UKM Melalui Pemberdayaan Peran Pemerintah Daerah. Jakarta: Bakrie School of Management.

Gosselin, M. (2005). An Empirical Study Of Performance Measurement in Manufacturing Firms. International Journal of Productivity and Performance Management, 54(5), 419-437.

Hafsah, M. J. (2000). Kemitraan Usaha: Konsepsi dan Strategi. Jakarta: Pustaka SinarHarapan.

Hatta, I. H. (2015). Orientasi Pasar, Orientasi Kewirausahaan, Kapabilitas Pemasaran dan Kinerja Pemasaran. Jurnal Aplikasi Manajemen, 13(4), 653-661.

Homburg, C., Artz, M., \& Wieseke, J. (2012). Marketing Performance Measurement Systems: Does Comprehensiveness Really Improve Performance? Journal of Marketing, 76(3), 56-77. https://doi.org/10.1509/jm.09.0487

Jogaratnam, G., \& Tse, E. C. (2006). Entrepreneurial Orientation and The Structuring of Organizations: Performance Evidence from The Asian Hotel Industry. International Journal of Contemporary Hospitality Management, 18(6), 454-468. https://doi.org/10.1108/09596110610681502

Keil, T., Maula, M., \& Syrigos, E. (2017). CEO Entrepreneurial Orientation, Entrenchment, and Firm Value Creation. Entrepreneurship Theory and Practice, 41(4), 475-504. https://doi.org/10.1111/etp.12213

Lages, L. F., \& Sousa, C. M. (2010). Export Performance. In Wiley International Encyclopedia of Marketing. John Wiley \& Sons, Inc.

Lee, D. Y., \& Tsang, E. W. K. (2001). The Effect of Entrepreneurial Personality, Background and Network Activities on Venture Growth. Journal of Management Studies, 38(4), 583-602. https://doi.org/10.1111/1467-6486.00250

Leonidou, L. C., Katsikeas, C. S., \& Samiee, S. (2002). Marketing Strategy Determinants of Export Performance: A Meta-analysis. Journal of Business Research, 55(1), 51-67. https://doi.org/10.1016/S0148-2963(00)00133-8

Li, Y., Zhao, Y., Tan, J., \& Liu, Y. (2008). Moderating Effects of Entrepreneurial Orientation on Market Orientation-Performance Linkage: Evidence from Chinese Small Firms. Journal of Small Business Management, 46(1), 113-133. https://doi.org/10.1111/j.1540-627X.2007.00235.x

Miller, D., \& Friesen, P. H. (1982). Innovation in Conservative and Entrepreneurial Firms: Two Models of Strategic Momentum. Strategic Management Journal, 3(1), 1-25.

Mohr, J., \& Spekman, R. (1994). Characteristics of Partnership Success: Partnership Attributes, Communication Behavior, and Conflict Resolution Techniques. Strategic Management Journal, 15(2), 135-152. https://doi.org/10.1002/smj.4250150205

Morris, M. H., Schindehutte, M., \& LaForge, R. W. (2002). Entrepreneurial Marketing: A Construct for Integrating Emerging Entrepreneurship and Marketing Perspectives. Journal of Marketing Theory and Practice, 10(4), 1-19. https://doi.org/10.1080/10696679.2002.11501922

Naldi, L., Nordqvist, M., Sjöberg, K., \& Wiklund, J. (2007). Entrepreneurial Orientation, Risk Taking, and Performance in Family Firms. Family Business Review, 20(1), 33-47. https://doi.org/10.1111/j.1741-6248.2007.00082.x

Narver, J. C., \& Slater, S. F. (1990). The Effect of Market Orientation on Business Profitability. Journal of Marketing, 54(4), 20-35. https://doi.org/10.1177/002224299005400403

Okpara, J. O., \& Kabongo, J. D. (2009). Entrepreneurial Export Orientation, Strategy, and Performance of SMEs in An Emergent African Economy. African Journal of Business and Economic Research, 4(2_3), 34-54.

Racela, O. C., \& Thoumrungroje, A. (2014). Export Market Orientation, Interfirm Communication, Interfirm Cooperation and Export Performance. International Journal of Management and Marketing Research, 7(1), 1-14.

Rauch, A., Wiklund, J., Lumpkin, G. T., \& Frese, M. (2009). Entrepreneurial Orientation and Business Performance: Cumulative Empirical Evidence. Entrepreneurship Theory and Practice, 33(3), 761-787. https://doi.org/10.1111/j.1540-6520.2009.00308.x

Shoham, A. (1998). Export Performance: A Conceptualization and Empirical Assessment. Journal of International Marketing, 6(3), 59-81. https://doi.org/10.1177/1069031X9800600308

Suryana. (2013). Kewirausahaan; Kiat dan Proses Menuju Sukses. Jakarta: Salemba Empat.

Van Zyl, H. J., \& Mathur-Helm, B. (2007). Exploring A Conceptual Model, Based on the Combined 
Effects of Entrepreneurial Leadership, Market Orientation and Relationship Marketing Orientation on South Africa's Small Tourism Business Performance. South African Journal of Business Management, 38(2), 17-24.

Varadarajan, P. R., \& Jayachandran, S. (1999). Marketing Strategy: An Assessment of the State of the Field and Outlook. Journal of the Academy of Marketing Science, 27(2), 120-143. https://doi.org/10.1177/0092070399272002

Webb, J. W., Ireland, R. D., Hitt, M. A., Kistruck, G. M., \& Tihanyi, L. (2011). Where Is The Opportunity Without The Customer? An Integration of Marketing Activities, The Entrepreneurship Process, and Institutional Theory. Journal of the Academy of Marketing Science, 39(4), 537-554. https://doi.org/10.1007/s11747-010-0237-y

Zahra, S. A. (2018). Entrepreneurial Risk Taking in Family Firms: The Wellspring of the Regenerative Capability. Family Business Review, 31(2), 216-226. https://doi.org/10.1177/0894486518776871

Zimmerer, T. W., \& Scarborough. (2005). Essentials Of Entrepeneurship and Small Business Management: the foundations of entrepeneurship the united states of America. Person Education. 